\title{
KARAKTERISTIK GEOKIMIA BATUAN INDUK FORMASI WALAT, KABUPATEN SUKABUMI, PROVINSI JAWA BARAT
}

\section{GEOCHEMICAL CHARACTERISTICS OF WALAT FORMATION SOURCE ROCK, SUKABUMI REGENCY, WEST JAVA PROVINCE}

\author{
Nisa Nurul IImi dan Aldrin Ramadian \\ Fakultas Teknik Geologi, Universitas Padjadjaran \\ nisa.nurul.ilmi@unpad.ac.id
}

\begin{abstract}
ABSTRAK
Kajian karakteristik geokimia batuan induk Formasi Walat di Sukabumi, Jawa Barat merupakan suatu langkah untuk mendapatkan informasi mengenai sistem minyak dan gas bumi yang ada. Lebih lanjut lagi, kajian ini juga diharapkan dapat mengungkap kesamaan sistem minyak dan gas bumi di daerah studi, dengan potensi hidrokarbon terbukti di Cekungan Jawabarat Utara. Kekayaan material organik, tingkat kematangan, serta tipe hidrokarbon yang dihasilkan merupakan parameter penting yang menunjukkan karakter batuan induk secara geokimia. Sistematika pemercontohan singkapan Formasi Walat yang diyakini berpotensi sebagai batuan induk, dianalisis ke laboratorium untuk penyelidikan karakteristik geokimia. Sebanyak tujuh belas percontoh terpilih, dan selanjutnya dianalisis karakter geokimianya melalui parameter Total Organic Carbon dan Rock Eval Pyrolysis (nilai S1, S2, dan S3 beserta turunannya).

Berdasarkan tingkat kematangan, semua percontoh berada pada tingkatan matang hingga matang akhir dengan kualitas kerogen tipe III yang menghasilkan gas. Hasil penelitian menunjukkan bahwa Formasi Walat memiliki karakter batuan induk dengan kekayaan sedang hingga sangat baik, dan memiliki potensi untuk menghasilkan hidrokarbon jenis gas. Berdasarkan penemuan sumber batuan induk potensial di formasi ini, maka dapat dikatakan bahwa di daerah studi terdapat sistem minyak dan gas bumi yang setara dengan Cekungan Jawabarat Utara, sehingga eksplorasi migas pada wilayah selatan Jawa Barat menjadi menarik.
\end{abstract}

Kata kunci: batuan induk, geokimia, hidrokarbon, Formasi Walat, Cekungan Jawabarat Selatan

\begin{abstract}
A study on potential of the Walat Formation's source rock in Sukabumi, West Java is a way to gain information about the existing petroleum system in the area. Furthermore, this study was also a way to reveal the similarity between the proven hydrocarbon potential in the North West Java Basin. Organic matter richness, maturity, as well as the type of hydrocarbon generated from the source are significant parameters to show source rocks characteristics geochemically. A systematic sampling of the rock was carried out and=tested to investigate its geochemical characteristics. Seventeen selected samples were analysed to obtain the data of Total Organic Carbon and Rock Eval Pyrolysis with values of S1, S2, S3 and its derived values. Laboratory analysis along with a thorough interpretation reveals that this formation is currently in a mature stage that has fair to very good organic matter richness. Furthermore, the organic matter type of the formation shows that this source rock could produce and generate gas. The discovery of potential source rock may indicates the existence of an equivalent petroleum system with the one proven in the North West Java Basin. Thus, the exploration in the southern part of West Java is more interesting.
\end{abstract}

Keywords: source rock, geochemistry, hydrocarbon, Walat Formation, South West Java Basin 


\section{PENDAHULUAN}

Penelitian mengenai batuan induk Formasi Walat, Sukabumi, Jawa Barat ini dilakukan di Cekungan Jawa Barat Selatan. Penelitian ini merupakan salah satu upaya untuk memahami sistem minyak dan gas bumi yang ada di wilayah studi, dengan membandingkannya terhadap Cekungan Jawa Barat Utara yang telah terbukti sebagai lapangan migas berproduksi yang dikelola Pertamina ONWJ semenjak tahun 1977, (Darman dan Sidi, 2000). Keterdapatan hidrokarbon di Cekungan Jawa bagian utara merupakan suatu permulaan untuk dapat melihat adanya kesetaraan antara Cekungan Jawa bagian Selatan dengan Cekungan Jawa Barat Utara yang sudah terbukti dan dapat memproduksi hidrokarbon. Hasil penelitian ini diharapkan dapat menjadi suatu kontribusi bagi penemuan cadangan strategis di Indonesia.

Formasi Walat disusun oleh batuan sedimen nonmarine berumur Paleogene (Eosen Akhir-Oligosen Awal) yang sangat menarik untuk dapat dieksplorasi. Lingkungan pengendapan Formasi Walat yang dapat dikatakan berada pada tataan fluvio-delta merupakan suatu nilai tambah bagi formasi ini. Pasokan material organik yang beragam pada sedimen yang diendapkan dalam formasi ini dapat menghasilkan karakteristik hidrokarbon yang juga memiliki keunikan tersendiri. Penelitian ini bertujuan untuk mengetahui potensi batuan induk dari sedimen yang diendapkan pada Formasi Walat di daerah Sukabumi, Jawa Barat.

Proses identifikasi batuan induk merupakan suatu langkah awal yang dilakukan untuk menyediakan informasi lengkap mengenai batuan induk. Informasi yang bisa disediakan dari analisis geokimia batuan induk ini meliputi kekayaan material organik, tipe material organik, serta kematangan termal dari batuan induk (Peters dan Cassa, 1994). Infromasi mengenai batuan induk juga dapat sangat berguna untuk menjelaskan suatu area secara geologi maupun stratigrafi dari suatu batuan induk dalam sistem minyak dan gas bumi. Lebih lanjut lagi, informasi mengenai batuan induk dapat digunakan untuk menentukan jumlah serta tipe hidrokarbon yang digenerasikan dari batuan induk tersebut (Peters dan Cassa, 1994). Studi mengenai batuan induk dalam proses eksplorasi menjadi suatu tahapan yang sangat penting terutama untuk mengurangi risiko eksplorasi. Suatu batuan induk yang telah matang dapat menggenerasikan dan menghasilkan hidrokarbon, tergantung dari material organik yang terawetkan di dalam batuan sedimen selama proses pengendapan.

Evaluasi batuan induk dibutuhkan untuk mengetahui dan memetakan bagianbagian penting dari suatu sistem minyak dan gas bumi. Metode analisis yang paling umum digunakan untuk mengevaluasi batuan induk adalah analisis Total Organic Carbon (TOC), Rock-Eval Pyrolysis, dan analisis reflektansi vitrinit (Dembicki, 2009).

\section{GEOLOGI}

Menurut Martodjojo (2003), singkapan Formasi Walat di daerah Sukabumi setara dengan Formasi Bayah berumur Oligosen. Effendi dan Hermanto (1986) memberikan nama Formasi Walat untuk singkapan di Gunung Walat (G. Walat) dan Pasir Bongkok. Singkapan terluas formasi ini terdapat di daerah selatan Sukabumi, tepatnya di kompleks G. Walat dengan ketebalan minimum satuan mencapai 700 m (Baumann et al., 1973). Formasi ini juga tersingkap di daerah lain, yaitu di sebelah tenggara G. Walat yang dikenal sebagai Kompleks Pasir Aseupan (Sunardi dan Adhiperdana, 2013).

Formasi Walat di daerah selatan Sukabumi ini umumnya terdiri dari perselingan antara batupasir, konglomerat, dan batulempung yang mengandung batubara. Batupasir umumnya konglomeratan atau konglomerat pasiran. Berdasarkan ciri litologi serta banyaknya sisipan batubara, lingkungan pengendapan formasi ini menunjukkan daratan yang berhubungan dengan sedimentasi di lingkungan sungai atau fluvial (Sunardi dan Adhiperdana, 2013). 


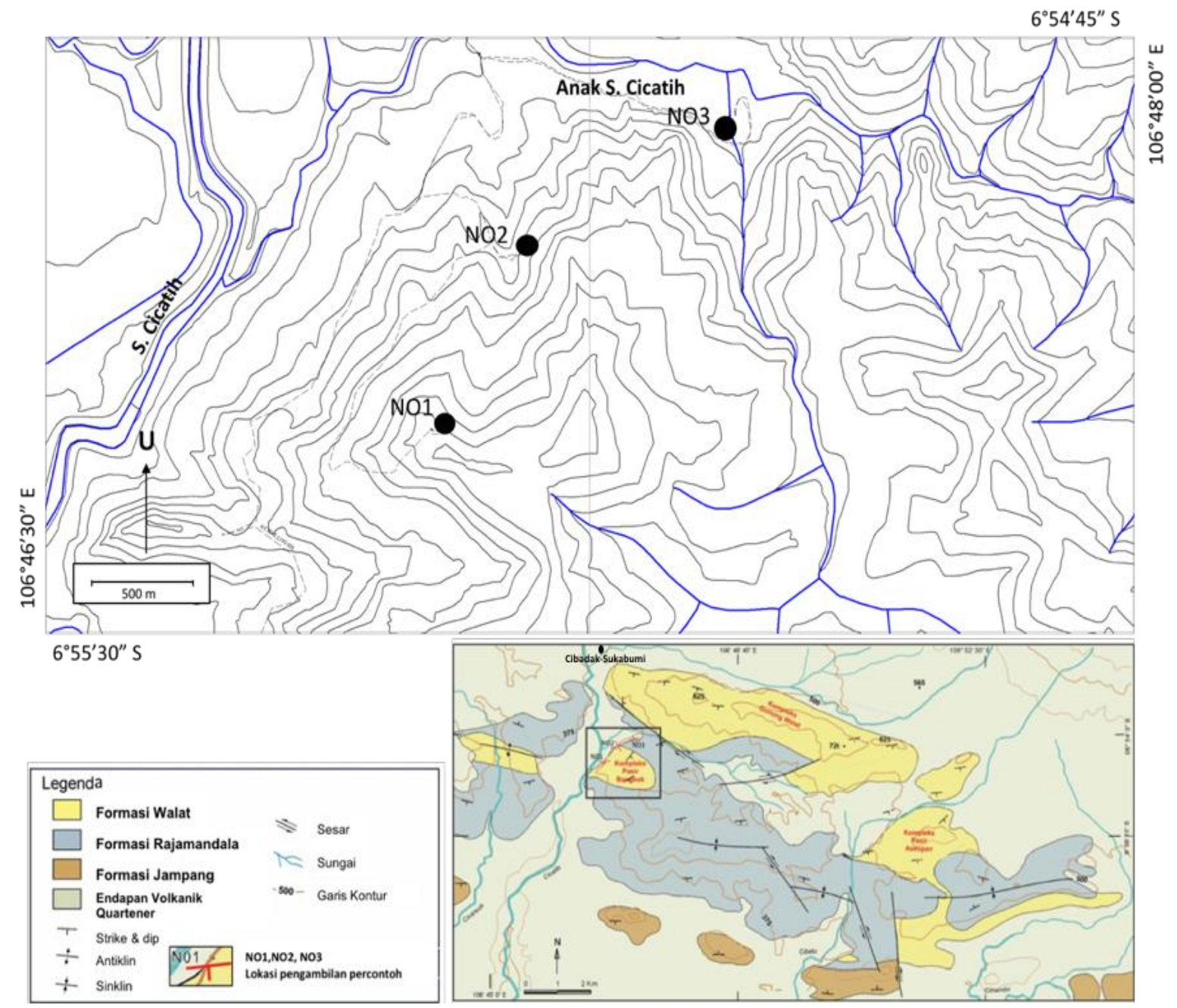

Gambar 1. Lokasi penelitian pada singkapan Formasi Walat di Kabupaten Sukabumi, Jawa Barat (Kotak berwarna hitam). NO1, NO2, dan NO3 merupakan lokasi pengambilan percontoh untuk analisis geokimia pada daerah studi.

Dimodifikasi dari Peta Geologi oleh Adhiperdana (2018)

Berdasarkan studi yang dilakukan Effendi dan Hermanto (1986), Formasi Walat terdiri dari batupasir kuarsa berlapis silang, konglomerat kuarsa, batulempung karbonatan, dan batubara lignit. Pada posisi yang lebih tinggi, tepatnya di daerah Cibadak, G. Walat, besar butir yang ditemukan lebih kasar dari daerah lain. Bagian selatan Jawa Barat merupakan area eksplorasi minyak dan gas bumi dengan data sumur eksplorasi yang minim, serta data prospek hidrokarbon yang belum teridentifikasi (Samuel dan Mujito, 1976). Beberapa sistem minyak dan gas bumi mungkin masih belum terungkap di area ini, dan diyakini berada di dalam sedimen yang terendapkan pada cekungan Paleogen transtensional, cekungan Neogene, atau cekungan intra-arc. Di daerah ini diperkirakan terdapat pula subcekungan yang terbentuk dengan ketebalan sedimen yang bervariasi, dipisahkan oleh sesar, dan memiliki prospek hidrokarbon yang signifikan (Sunardi dan Adhiperdana, 2008).

Formasi batuan berumur Paleogen yang dianggap setara dengan Formasi Walat di Cekungan Jawabarat Utara khususnya pada Dalaman Babadan adalah Formasi Jatibarang (Purnomo dkk., 2006). Unit stratigrafi Paleogen terdiri dari Formasi Jatibarang dan Talangakar. Formasi Jatibarang, berdasarkan karakteristik litologi, posisi seismik stratigrafi dan kontrol genesis dibagi menjadi 3 unit, yaitu JTB-02, JTB-01 dan Top JTB. Litologinya 
terdiri dari batulempung hitam yang banyak mengandung material organik, beberapa lapisan batubara, batupasir, konglomerat dan vulkanik klastik (Purnomo dkk., 2006). Lingkungan pengendapan berdasarkan analisis palinologi adalah daratan, dengan umur yang dapat dikorelasikan dengan Zonasi Blow P14-P16 atau sekitar 43-37 juta tahun yang lalu (Eosen Tengah-Eosen Akhir). Formasi Jatibarang merupakan endapan lakustrin klastik dan vulkanik klastik. Pada formasi ini, batuan induk dicirikan oleh endapan klastik nonmarine berukuran kasar dan perselingan antara batupasir dengan serpih lakustrin. Batuan induk tipe ini menghasilkan minyak dan gas (Remington dan Pranyoto, 1985).

\section{METODOLOGI}

Percontoh diambil langsung dari lapangan yang diawali dengan pembuatan penampang stratigrafi terukur melalui batulempung menyerpih pada Formasi Walat yang tersingkap di area Pasir Bongkok, Sukabumi, Jawa Barat sesuai dengan Peta Geologi Lembar Bogor oleh Effendi dan Hermanto (1986) (Gambar 1). Pengambilan percontoh batuan dilakukan
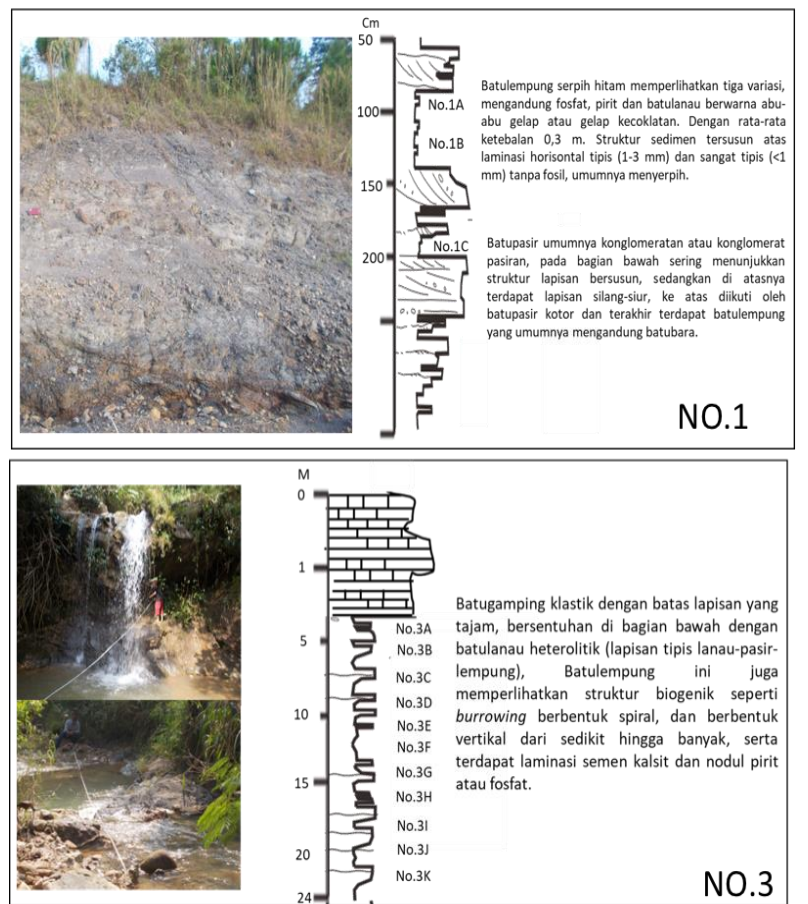

Batugamping klastik dengan batas lapisan yang tajam, bersentuhan di bagian bawah dengan batulanau heterolitik (lapisan tipis lanau-pasirlempung), Batulempung burrowing berbentuk biogenik seperti vertikal dari sedikit hine banvak, serta terdapat laminasi semen kalsit dan nodul pirit atau fosfat.

NO.3 di dua lokasi, yaitu singkapan yang berada pada kompleks Pasir Bongkok dan Anak sungai Cicatih (Gambar 1). Pengambilan percontoh dilakukan secara sistematis pada penampang stratigrafi yang telah dibuat secara detail sebelumnya. Pemilihan percontoh berdasarkan pengamatan secara visual, terutama pada batuan yang berbutir halus mengandung material organik yang diyakini sebagai batuan induk (Gambar 2). Posisi percontoh ditandai dan diberi kode, baik pada log litologi maupun pada kantong percontoh.

Seluruh percontoh yang telah dipilih kemudian dianalisis di Laboratorium Lemigas, Cipulir, Jakarta Selatan dengan metode TOC (Total Organic Carbon) dan Rock-Eval Pyrolysis. Data yang didapat dari kedua metode analisis ini kemudian diolah untuk menghasilkan karakteristik dari batuan induk yang diteliti.

Prosedur yang dilakukan oleh analis di Laboratorium Lemigas beserta kondisi analisis dilakukan berdasarkan Peters (1986) dan Peters dan Cassa (1994). Data yang didapat dari hasil metode pirolisis dapat dilihat pada Tabel 1.
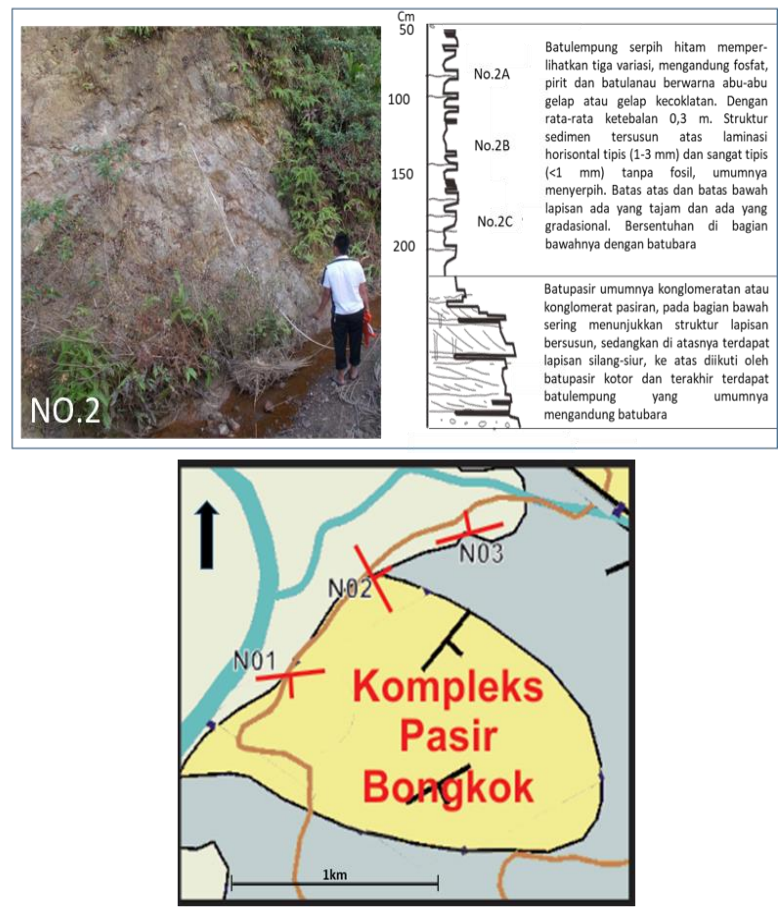

Gambar 2. Lokasi pengambilan percontoh pada singkapan batuan Formasi Walat di Kompleks Pasir Bongkok (NO1, dan NO2) dan di Anak sungai Cicatih (NO3) secara sistematis berdasarkan urutan batuan secara vertikal terhadap beberapa unit lapisan batuan 


\section{HASIL DAN PEMBAHASAN Hasil}

Hasil pengamatan geologi di lapangan menunjukkan bahwa lokasi pemercontohan pada kedua lokasi (G. Walat, dengan kode NO1 dan NO2, dan Anak sungai Cicatih, dengan kode NO3) dapat disarikan berikut ini.

Stratotipe Formasi Walat di Anak sungai Cicatih, dimulai dengan endapan lempung-pasir pantai yang tersingkap di tepi pantai, sekitar $200-250 \mathrm{~m}$ di sebelah timur muara Anak sungai Cicatih. Gosong pasir di daerah ini mempunyai kemiringan hampir tegak lurus dengan bagian atas menghadap ke selatan, sebagaimana terlihat dari terpotongnya busur lapisan silang-siur pada singkapan itu. Batas antara singkapan ini dengan singkapan lain dari Formasi Walat di Anak sungai Cicatih tertutup oleh endapan pantai.

Di Anak sungai Cicatih, Formasi Walat bagian bawah, umumnya terdiri dari pasir kuarsa, sedangkan bagian atasnya terdiri dari perselingan antara batupasir dan batulempung yang mengandung batubara. Penyelidikan detail Zielger (1918) menemukan sembilan (9) lapisan batubara dengan ketebalan maksimal single seam sebesar $110 \mathrm{~cm}$. Pada penyelidikan ini ditemukan lebih dari 10 lapisan batubara, dengan ketebalan maksimum single seam sebesar $180 \mathrm{~cm}$. Batupasirnya mempunyai ketebalan mulai dari $3 \mathrm{~m}$ sampai $12 \mathrm{~m}$, dengan batas bawah tegas, sedangkan bagian atas berubah berangsur ke lapisan batulempung yang mengandung bitumen (bituminous shale). Struktur silang-siur sering terdapat di bagian bawahnya yang kadang-kadang konglomeratan. Ciri tubuh batupasir seperti ini sangat khas untuk endapan fluviatil yang berkelok-kelok.

Di lokasi G. Walat, Formasi Walat memperlihatkan perselingan antara batupasir konglomeratan yang berstruktur silang-siur dengan batulempung yang mengandung batubara. Ketebalan batulempung yang mengandung batubara pada lokasi ini mencapai 1 meter. Endapan batupasir konglomeratan di daerah ini terdiri dari empat (4) kompleks singkapan. Singkapan terbesar terdapat di G. Walat, yang memanjang dengan arah barat-timur sejajar dengan jalan Sukabumi-Cibadak sepanjang $9 \mathrm{~km}$. Singkapan lain yang agak terpisah berada di sebelah tenggara G. Walat yang juga dikenal sebagai Kompleks Pasir Aseupan (Gambar 1). Selain itu terdapat pula singkapan di daerah yang dikenal dengan nama Kompleks Pasir Bongkok yang berada di selatan $\mathrm{G}$. Walat. Pasir Bongkok dan G. Walat dipisahkan oleh lembah sinklin yang tersesarkan (Gambar 1). Daerah lain yang penting adalah di sebelah barat Pasir Bongkok, yaitu di S. Cicareuh.

Dari penelitian lapangan di daerah Sukabumi, singkapan pada S. Cicareuh merupakan anggota batuan Formasi Walat yang secara stratigrafi berada di urutan paling bawah dengan ketebalan singkapan sekitar $590 \mathrm{~m}$. Pada bagian terbawah singkapan terdapat perlapisan batupasir dan batulempung karbonan tipis setebal $112 \mathrm{~m}$ bersama dengan sisipan napal berwarna abu-abu muda. Seluruh singkapan Batupasir, umumnya mempunyai ciri berbatas bawah tegas dan bagian atas relatif berangsur. Pada bagian tengah singkapan, batuannya lebih bersifat konglomeratan, yang menunjukkan pola seperti pada endapan sungai teranyam (Adhiperdana, 2018; Martodjojo, 1984). Pada bagian paling atas, singkapan batuan menunjukkan perselingan batulempung berwarna coklat, abu-abu dan batupasir.

Di daerah Pasir Bongkok (Gambar 1) terdapat singkapan batupasir yang berciri litologi seperti bagian tengah dan atas dari singkapan di S. Cicareuh. Singkapan paling bawah berupa batupasir dengan tebal lapisan $5 \mathrm{~m}$, berlapis silang-siur cekung, di bagian atas terdapat fragmen batubara kemudian di atasnya ditutupi batupasir konglomeratan $(6 \mathrm{~m})$ dan batupasir berlapis tebal $( \pm 1 \mathrm{~m})$. Arah umum jurus perlapisan batuan $\mathrm{N} 190^{\circ} \mathrm{E}$, pada beberapa tempat terdapat bioturbasi vertikal.

Bagian teratas dari singkapan batuan di daerah Pasir Bongkok terdiri dari perse- 
lingan batupasir dan batulempung coklat dengan sisipan batubara atau lempung bitumen. Tebal keseluruhan penampang di Pasir Bongkok adalah $110 \mathrm{~m}$.

Singkapan terluas terdapat di G. Walat. Di daerah ini, umumnya terdiri dari perselingan antara batupasir-konglomerat dan batulempung yang mengandung batubara. Batupasir umumnya konglomeratan atau konglomerat pasiran, pada bagian bawah sering menunjukkan struktur lapisan bersusun, sedangkan di bagian atas terdapat lapisan silang-siur, kemudian diikuti oleh batupasir kotor dan terakhir terdapat batulempung yang umumnya mengandung batubara. Batupasir memiliki ketebalan 4 sampai 7 $\mathrm{m}$, sedangkan sisipan batubara umumnya $10 \mathrm{~cm}$ sampai $100 \mathrm{~cm}$.

Berdasarkan ciri litologi, terutama struktur sedimen, komposisi butir, dan banyaknya sisipan batubara, maka lingkungan pengendapan dari Formasi Walat adalah lingkungan darat (Cant, 1982; Coleman dan Prior, 1982). Bagian bawahnya, menunjukkan pengendapan fluviatil dengan tipe sungai teranyam dan berakhir sampai kelokan sungai dan/ atau delta.

Dari pengukuran pengarahan butir kerakal dan arah lapisan silang-siur, dapat ditentukan arah arus dan asal-usul batuan yang kemungkinan berasal dari utaratimur laut daerah penelitian. Penyelidikan mineral berat dapat menyimpulkan bahwa batupasir konglomeratan Formasi Walat berasal dari batuan beku granitan dan malihan (Clements dan Hall, 2007; Martodjojo, 1984).
Batulempung menyerpih berwarna hitam dan batulanau berwarna abu-abu gelap atau gelap kecoklatan. Ketebalannya berkisar antara 0,2-6 m, dengan rata-rata ketebalan 0,3 m. Struktur sedimen tersusun atas laminasi horisontal tipis (1-3 $\mathrm{mm})$ dan sangat tipis $(<1 \mathrm{~mm})$ tanpa fosil, umumnya menyerpih. Batas atas dan batas bawah lapisan menunjukkan batas tajam dan gradasional. Batas bagian bawah berupa batubara, batugamping mudstone dan batulanau heterolitik (lapisan tipis lanau-pasir-lempung), sedangkan batas bagian atas berupa batulempung kelabu atau batugamping mudstone. Batulempung ini juga memperlihatkan struktur biogenik seperti burrowing berbentuk spiral, dan berbentuk vertikal dengan jumlah sedikit hingga banyak Cangkang fosil yang terkandung umumnya berupa pecahan cangkang (disartikulasi), serta terdapat laminasi semen kalsit dan nodul pirit atau fosfat.

Batulempung hitam memperlihatkan struktur yang menunjukkan bahwa litologi ini diendapkan di bawah pengaruh sedimen suspensi dengan energi yang rendah dalam kondisi anoxic dari lingkungan laut lepas (Bouma et al., 1982; Cant, 1982).

Studi geokimia organik telah dilakukan untuk menganalisis 17 percontoh dari dua (2) lokasi yang berbeda untuk singkapan Formasi Walat. Studi ini melibatkan pengujian TOC dan Rock Eval Pyrolysis dan hasilnya dapat dilihat pada Tabel 1.

Tabel 1. Hasil analisis TOC dan Rock Eval Pyrolysis untuk percontoh batulempung Formasi Walat yang diambil dari tiga

(3 lokasi berbeda di Kabupaten Sukabumi, Provinsi Jawa Barat)

\begin{tabular}{|c|c|c|c|c|c|c|c|c|c|c|}
\hline \multicolumn{11}{|c|}{ Data TOC dan Pirolisis } \\
\hline \multirow{2}{*}{ No. } & \multirow{2}{*}{$\begin{array}{c}\text { Kode } \\
\text { Percontoh }\end{array}$} & \multirow{2}{*}{$\begin{array}{l}\text { TOC } \\
\text { (\%) }\end{array}$} & S1 & S2 & S3 & $T_{\text {maks }}$ & PY & $\mathbf{P I}$ & $\mathrm{HI}$ & Ol \\
\hline & & & \multicolumn{3}{|c|}{$\mathrm{mg} \mathrm{HC} / \mathrm{g}$ contoh batuan } & \multicolumn{5}{|c|}{$\left({ }^{\circ} \mathrm{C}\right)$} \\
\hline 1 & NO1.A & 2,41 & 0,12 & 1,67 & 0,35 & 440 & 1,79 & 0,07 & 69 & 15 \\
\hline 2 & NO1.B & 1,91 & 0,08 & 1,18 & 0,39 & 443 & 1,26 & 0,06 & 62 & 20 \\
\hline 3 & NO1.C & 3,66 & 0,14 & 3,93 & 0,05 & 439 & 4,07 & 0,03 & 107 & 1 \\
\hline 4 & NO2.A & 0,50 & 0,06 & 0,24 & 0,09 & 458 & 0,30 & 0,20 & 48 & 18 \\
\hline
\end{tabular}




\begin{tabular}{|c|c|c|c|c|c|c|c|c|c|c|}
\hline \multicolumn{11}{|c|}{ Data TOC dan Pirolisis } \\
\hline \multirow{2}{*}{ No. } & \multirow{2}{*}{$\begin{array}{c}\text { Kode } \\
\text { Percontoh }\end{array}$} & \multirow{2}{*}{$\begin{array}{c}\text { TOC } \\
\text { (\%) }\end{array}$} & S1 & S2 & S3 & $T_{\text {maks }}$ & PY & PI & HI & Ol \\
\hline & & & \multicolumn{3}{|c|}{$\mathrm{mg} \mathrm{HC} / \mathrm{g}$ contoh batuan } & \multicolumn{5}{|c|}{$\left({ }^{\circ} \mathbf{C}\right)$} \\
\hline 5 & NO2.B & 0,67 & 0,09 & 0,53 & 0,07 & 446 & 0,62 & 0,15 & 79 & 10 \\
\hline 6 & NO2.C & 0,99 & 0,07 & 0,58 & 0,17 & 446 & 0,65 & 0,11 & 59 & 17 \\
\hline 7 & NO3.A & 0,71 & 0,08 & 0,40 & 0,09 & 451 & 0,48 & 0,17 & 56 & 13 \\
\hline 8 & NO3.B & 0,74 & 0,08 & 0,52 & 0,05 & 444 & 0,60 & 0,13 & 70 & 7 \\
\hline 9 & NO3.C & 0,82 & 0,08 & 0,60 & 0,05 & 447 & 0,68 & 0,12 & 73 & 6 \\
\hline 10 & NO3.D & 0,87 & 0,08 & 0,58 & 0,32 & 445 & 0,66 & 0,12 & 67 & 37 \\
\hline 11 & NO3.E & 0,97 & 0,08 & 0,62 & 0,10 & 446 & 0,70 & 0,11 & 64 & 10 \\
\hline 12 & NO3.F & 0,52 & 0,07 & 0,28 & 0,25 & 453 & 0,35 & 0,20 & 54 & 48 \\
\hline 13 & NO3.G & 0,47 & 0,07 & 0,26 & 0,16 & 447 & 0,33 & 0,21 & 55 & 34 \\
\hline 14 & $\mathrm{NO} 3 . \mathrm{H}$ & 0,54 & 0,06 & 0,27 & 0,41 & 448 & 0,33 & 0,18 & 50 & 76 \\
\hline 15 & NO3.I & 0,68 & 0,08 & 0,40 & 0,31 & 444 & 0,48 & 0,17 & 59 & 46 \\
\hline 16 & NO3.J & 0,72 & 0,07 & 0,45 & 0,26 & 439 & 0,52 & 0,13 & 63 & 36 \\
\hline 17 & NO3.K & 0,91 & 0,08 & 0,52 & 0,28 & 443 & 0,60 & 0,13 & 57 & 31 \\
\hline
\end{tabular}

Keterangan:

S1 : Jumlah Hidrokarbon bebas

S2 : Jumlah hidrokarbon yang dilepaskan kerogen

S3 : Karbondioksida organik

TOC : Total Organic Carbon
PY : Pyolysis Yield, Jumlah total hidrokarbon $=(\mathrm{S} 1+\mathrm{S} 2)$

PI : Production Index, Indeks Produksi = $(\mathrm{S} 1 /(\mathrm{S} 1+\mathrm{S} 2))$

$\mathrm{T}_{\text {maks }} \quad$ : Suhu maksimum $\left({ }^{\circ} \mathrm{C}\right)$ pada puncak S2

$\mathrm{HI}$ : Hydrogen Index, Indeks Hidrogen = (S2/TOC) x 100

OI : Oxygen Index, Indeks Oksigen = (S3/TOC) x 100

Berdasarkan nilai PI yang didapat dari hasil Rock Eval Pyrolysis, kesebelas percontoh yang dianalisis ini memiliki nilai PI yang berada pada kisaran 0,11-0,21. Nilai PI yang ditunjukkan oleh percontoh yang terdapat di daerah tersebut mengindikasikan sudah tercapainya tingkat kematangan dari material organik yang terkandung di dalam percontoh tersebut.

Material organik dapat diklasifikasikan berdasarkan tipe kerogennya. Tissot dan Welte (1985) mengklasifikasikan kerogen ke dalam 3 tipe, yaitu tipe I, II, dan III. Sementara itu (Demaison et al., 1983) menambahkan 1 jenis kerogen, yaitu tipe IV ke dalam klasifikasi ini. Dalam mengklasifikasikan tipe kerogen, digunakan modifikasi dari diagram van Krevellen yang pertama kali digunakan oleh Tissot dan Welte (1985). 
Berdasarkan hasil pengeplotan pada modifikasi diagram van Kravelen, hampir semua percontoh yang dianalisis berada pada posisi kerogen tipe III, dan merupakan kerogen yang menghasilkan hidrokarbon jenis gas.

\section{Pembahasan}

Suatu batuan induk dikatakan memiliki potensi untuk menghasilkan hidrokarbon, apabila memiliki kandungan material organik tinggi yang ditunjukkan dengan nilai TOC, dan nilai potensial dalam menghasilkan hidrokarbon yang dapat dilihat dari hasil analisis metode Rock Eval Pyrolisis (nilai S1 dan S2) (Peters dan Cassa, 1994).

Nilai S1 dari suatu percontoh menunjukkan banyaknya hidrokarbon bebas yang terdapat dalam suatu percontoh batuan atau jumlah material organik yang terabsorpsi (bitumen) (Song et al., 2015). Percontoh yang diambil dari Kompleks Pasir Bongkok memiliki nilai S1 yang berada pada kisaran 0,06 sampai $0,14 \mathrm{mg} \mathrm{HC} / \mathrm{g}$ batuan dengan rata-rata nilai $\mathrm{S} 1 \quad 0,09 \mathrm{mg} \mathrm{HC} / \mathrm{g}$ batuan. Nilai ini menunjukkan bahwa hidrokarbon bebas yang terdapat di dalam percontoh (bitumen) relatif sedikit. Nilai $\mathrm{S} 1$ dari percontoh yang diambil di lokasi ke-2, yaitu di Anak sungai Cicatih, menunjukkan nilai yang berada pada kisaran 0,06-0,08 $\mathrm{mg} \mathrm{HC} / \mathrm{g}$ batuan dengan rata-rata $0,08 \mathrm{mg}$ $\mathrm{HC} / \mathrm{g}$ batuan. Nilai ini relatif lebih rendah dibandingkan dengan nilai $\mathrm{S} 1$ dari percontoh yang berasal dari Kompleks Pasir Bongkok dan mengindikasikan rendahnya hidrokarbon bebas yang dilepaskan.

Selanjutnya, nilai S2 dari analisis Rock Eval Pyrolysis menurut Song et al., (2015) menunjukkan jumlah hidrokarbon yang digenerasikan oleh proses pemecahan termal dari material organik yang tidak larut atau kerogen di dalam suatu batuan. Nilai S2 dari percontoh dari Kompleks Pasir Bongkok menunjukkan nilai bervariasi dengan kisaran 0,24-3,93 $\mathrm{mg}$ $\mathrm{HC} / \mathrm{g}$ batuan, dan rata-rata $\mathrm{S} 21,36 \mathrm{mg}$ $\mathrm{HC} /$ gram batuan. Nilai ini menunjukkan indikasi dari baiknya kualitas batuan induk dengan jumlah hidrokarbon cukup banyak yang berpotensi untuk digenerasikan. Sementara itu, percontoh yang berasal dari anak sungai Cicatih memiliki nilai S2 cenderung lebih rendah dengan rentang 0,27-0,62 $\mathrm{mg} \mathrm{HC} / \mathrm{g}$ batuan dari nilai ratarata $\mathrm{S} 20,45 \mathrm{mg} \mathrm{HC} / \mathrm{g}$ batuan. Nilai ini menunjukkan kualitas batuan induk yang rendah dengan potensial generasi hidrokarbon yang juga rendah.

Potensi percontoh batuan yang dianalisis juga dapat diketahui dengan mengeplotkan nilai TOC dan S2 dari percontoh yang dianalisis (Gambar 3 ). 


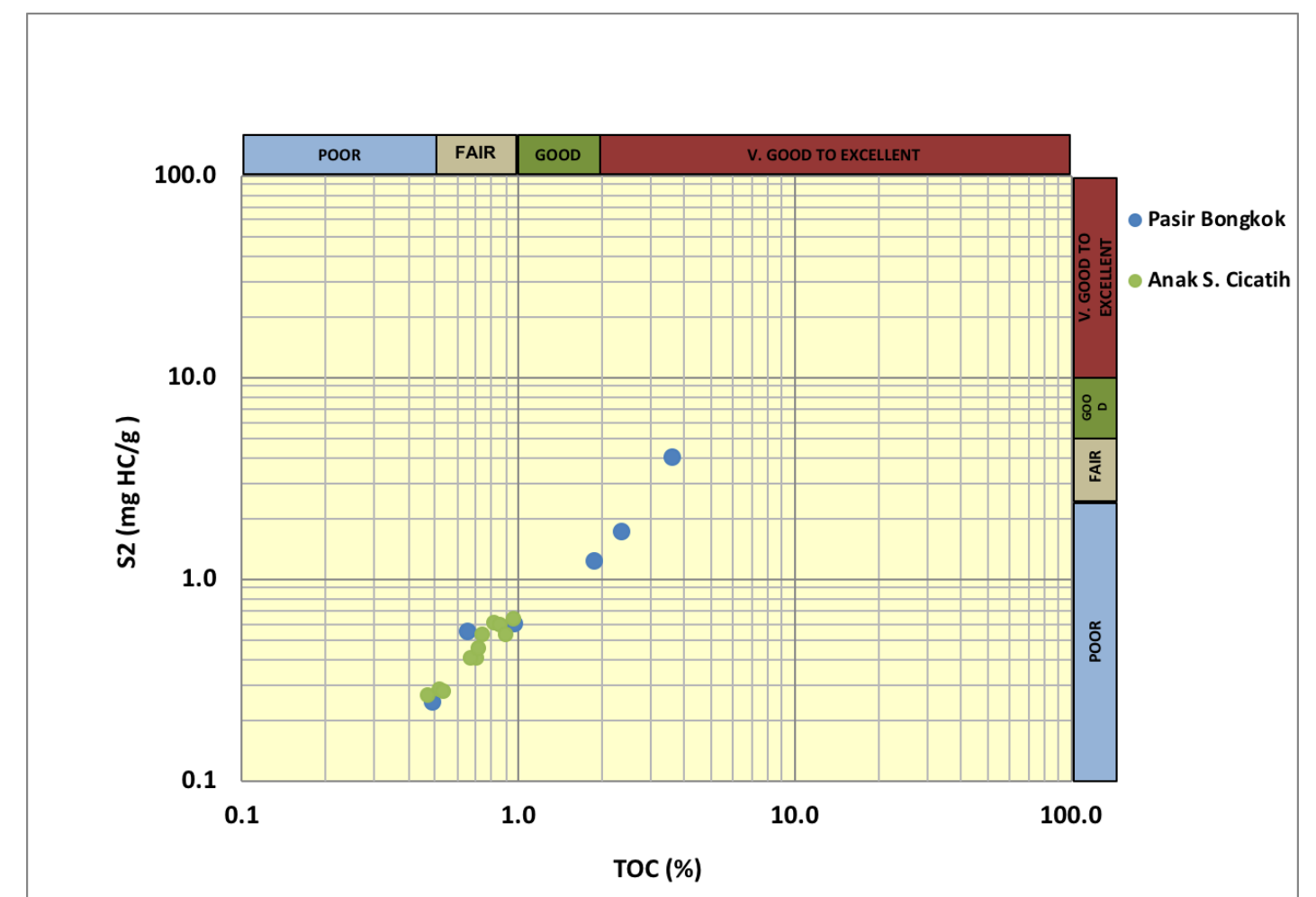

Gambar 3. Plot antara nilai S2 dan TOC dengan parameter kekayaan material organik untuk mengidentifikasi potensi percontoh dalam menghasilkan hidrokarbon, Peters dan Cassa (1994)

Berdasarkan plot antara nilai TOC dan S2, percontoh yang berasal dari Kompleks G. Walat dan Anak sungai Cicatih menunjukkan potensi batuan induk dari rendah sampai sedang. Sementara itu, terdapat tiga (3) percontoh yang menunjukkan kualitas batuan induk baik hingga sangat baik dari percontoh yang berasal dari Kompleks Pasir Bongkok, dengan potensial generasi hidrokarbon rendah hingga sedang (kode NO1-A, NO1-B, NO1-C).

Potensi batuan induk juga dapat dideskripsikan dengan nilai Indeks HIdrogen atau Hydrogen Index $(\mathrm{HI})$, yaitu nilai yang menunjukkan fraksi dari TOC yang digenerasikan sebagai hidrokarbon (Peters, 1986). Nilai HI percontoh dari Kompleks Pasir Bongkok memiliki nilai bervariasi antara 48-107 mg HC/TOC, dengan nilai $\mathrm{HI}$ rata-rata $71 \mathrm{mg} \mathrm{HC/TOC.}$ Sementara itu, percontoh yang diambil di lokasi anak sungai Cicatih memiliki nilai $\mathrm{HI}$ berkisar antara 50-73 mg HC/TOC dengan rata-rata nilai $\mathrm{HI} 61 \mathrm{mg} \mathrm{HC/TOC}$. Nilai-nilai yang ditunjukkan oleh keseluruhan percontoh yang dianalisis, mengarah pada tipe kerogen III yang menghasilkan hidrokarbon jenis gas (Peters dan Cassa, 1994).

Penggunaan diagram pseudo van Kravelen (Tissot dan Welte, 1985) menggunakan nilai $\mathrm{HI}$ dan $\mathrm{Ol}$ sebagai pengganti nilai $\mathrm{H} / \mathrm{C}$ dan $\mathrm{O} / \mathrm{C}$ yang didapat dari analisis elemen kerogen. Pada diagram ini, percontoh yang belum mencapai tingkat matang akan berada jauh dari nilai 0 , sementara semakin matangnya percontoh, maka nilainya akan semakin mendekati nilai 0 (Dembicki, 2009). Berdasarkan pengeplotan pada diagram pseudo van Kravelen (Gambar 4), semua percontoh berada pada posisi kerogen tipe III atau gas prone dengan posisi percontoh mendekati nilai 0 yang merupakan indikasi kematangan. 


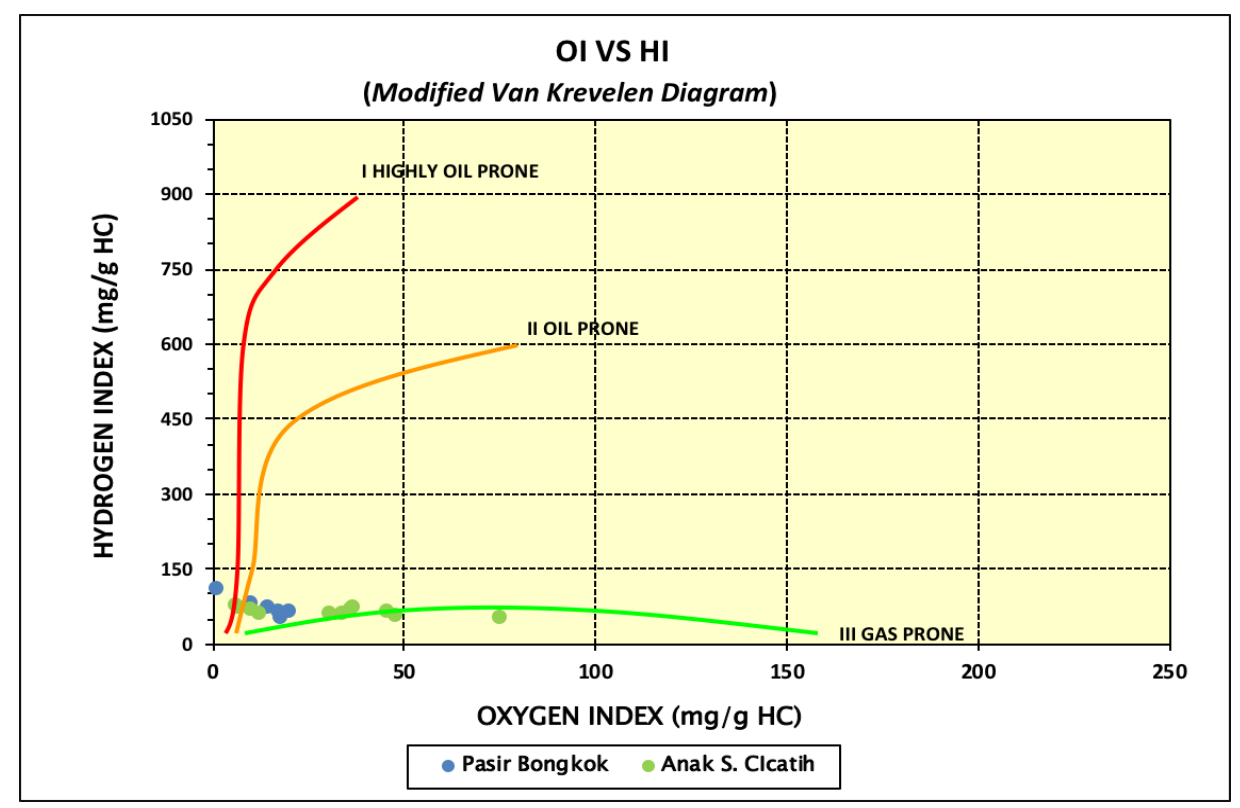

Gambar 4. Diagram pseudo van Krevelen untuk mendapatkan informasi mengenai tipe material organik dan jenis hidrokarbon yang dihasilkan

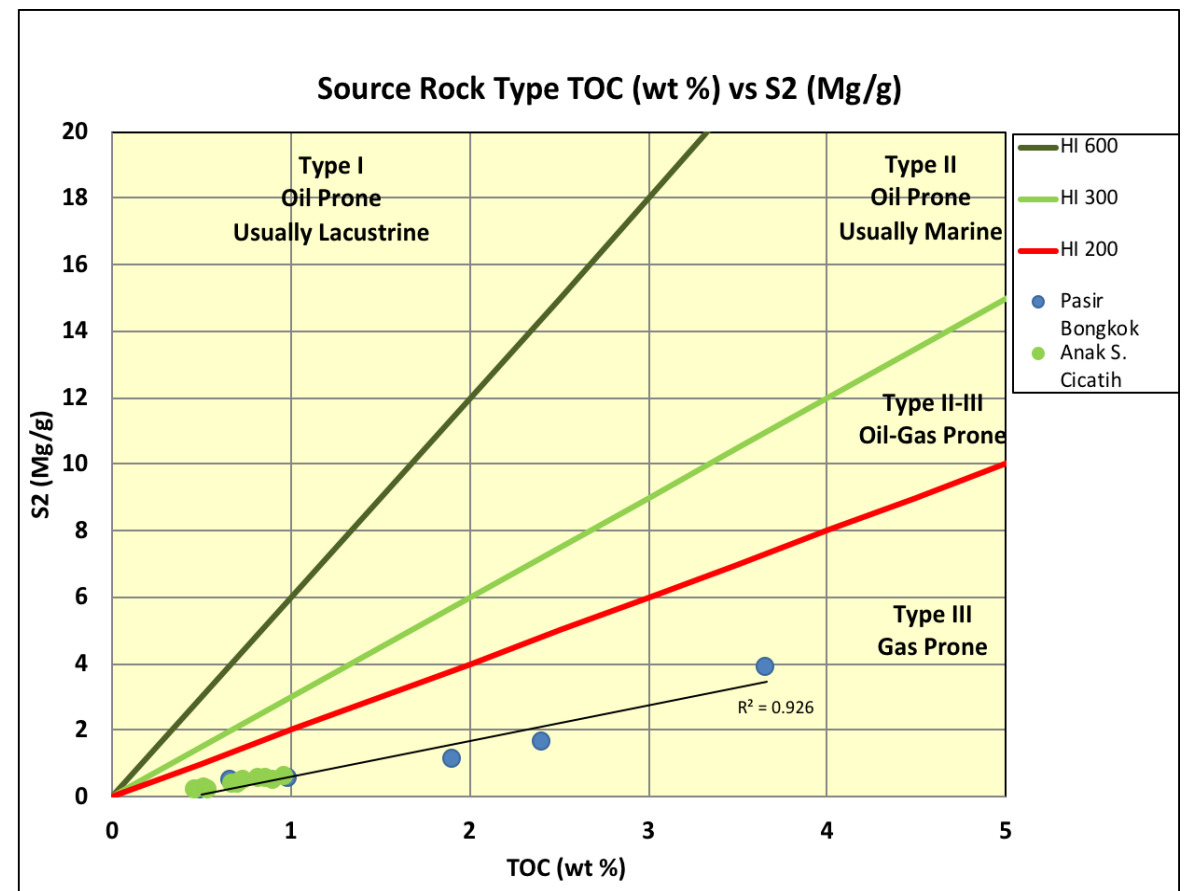

Gambar 5. Plot antara nilai TOC dan S2 untuk menunjukkan kesesuaian nilai HI hasil pengukuran dengan HI sebenarnya, Langford \& Blanc-Valleron (1990)

Untuk mengetahui sifat material organik dalam suatu sedimen, grafik antara S2 dan TOC dapat digunakan sebagai suatu alat analisis yang efektif (Langford dan Blanc-Valleron, 1990). Dalam proses analisis Rock Eval, seringkali didapati adanya efek mineral matriks yang kuat, sehingga nilai $\mathrm{HI}$ suatu percontoh dapat mengalami penurunan (Lüniger dan Schwark, 2002). Grafik ini menunjukkan nilai $\mathrm{HI}$ terkoreksi untuk memastikan material organik dari percontoh batuan sedimen (Gambar 5).

Grafik pada Gambar 5 menunjukkan kesesuaian nilai $\mathrm{HI}$ yang didapat dari hasil pengukuran oleh instrumen Rock Eval Pyrolisis dengan nilai $\mathrm{HI}$ terkoreksi yang didapat dari grafik. Hal ini menunjukkan kesesuaian antara hasil pengeplotan untuk mengetahui jenis material organik di dalam percontoh, dengan pengeplotan 
pada diagram van Krevelen. Berdasarkan hasil kedua metode analisis tersebut, material organik dari percontoh merupakan kerogen tipe III, yang cenderung menghasilkan gas. Sumber utama material organik kerogen tipe III adalah tanaman tingkat tinggi yang dapat terendapkan di laut dangkal hingga laut dalam, atau dapat juga terendapkan pada bukan lingkungan laut (McCarthy et al., 2011). Material organik dengan kerogen tipe III memiliki nilai HI yang lebih rendah dari kerogen tipe I maupun II, sehingga cenderung menghasilkan gas (gas prone) (McCarthy et al., 2011).

Rentang kematangan yang ditunjukkan oleh nilai Temperatur maksimum (Tmaks) dapat bervariasi untuk tipe material organik yang berbeda (Tissot dan Welte, 1985). Variasi nilai Tmaks untuk kerogen tipe I berada pada rentang yang cukup pendek, sementara variasi nilai Tmaks untuk kerogen tipe II dan III mempunyai rentang lebih panjang, karena kompleksitas dari material organik yang meningkat (Hakimi dan Abdullah, 2013).
Waples (1985) menyatakan bahwa suatu batuan induk dapat dikatakan matang, apabila hasil analisis Rock-Eval menunjukkan nilai Tmaks $>435^{\circ} \mathrm{C}$ atau nilai indeks produksi sebesar 0,1. Secara lebih lengkap, klasifikasi tingkat kematangan suatu percontoh dapat dilihat dari klasifikasi yang dilakukan oleh Espitalié et al. (1977). Percontoh yang belum matang memiliki nilai Tmaks $<435^{\circ} \mathrm{C}$, sementara Tmaks untuk percontoh yang berada pada posisi awal kematangan adalah $435-445^{\circ} \mathrm{C}$, diikuti dengan puncak kematangan pada 445$450^{\circ} \mathrm{C}$, kematangan akhir $450-470^{\circ} \mathrm{C}$, dan terlampau matang pada $>470^{\circ} \mathrm{C}$ (Espitalié, et al., 1977). Untuk mengetahui tingkat kematangan percontoh, dilakukan juga analisis dengan mengeplotkan nilai Tmaks terhadap nilai HI. Hasil pengeplotan ini dapat menunjukkan kualitas kerogen dan tingkat kematangan dari percontoh yang dianalisis (Gambar 6). Tingkat kematangan semua percontoh yang dianalisis berada pada tingkatan matang hingga matang akhir dengan kualitas kerogen tipe III yang menghasilkan gas.

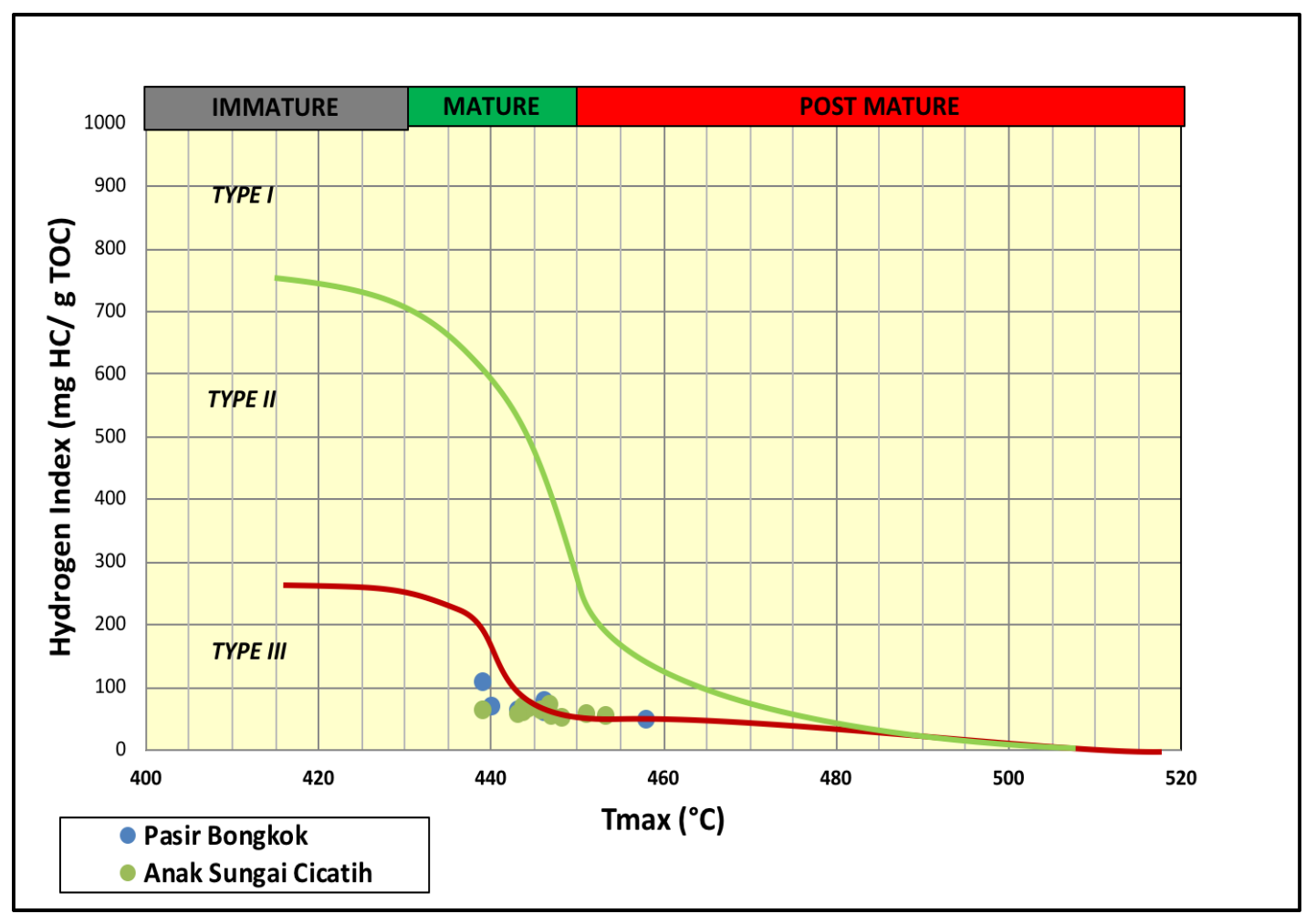

Gambar 6. Plot antara nilai Tmaks dan $\mathrm{HI}$ untuk mengetahui tingkat kematangan termal dari percontoh yang dianalisis serta jenis material organik yang terkandung di dalamnya 


\section{KESIMPULAN}

Hasil studi karakteristik batuan induk dari Formasi Walat menunjukkan kualitas yang sedang hingga baik dengan material organik yang bersumber dari tanaman tingkat tinggi (kerogen tipe III). Material organik yang terendapkan di Formasi Walat telah mencapai tingkatan matang dengan menggenerasikan hidrokarbon jenis gas. Formasi ini mempunyai kesamaan dengan Formasi Jatibarang berumur Paleogen, khususnya pada Dalaman Babadan yang berfungsi sebagai batuan induk, sehingga secara stratigrafi setara dengan Formasi Walat di daerah penelitian. Dengan demikian, eksplorasi minyak dan gas bumi tersebut pada wilayah selatan Jawa Barat menjadi menarik, mengingat terdapatnya sumber batuan induk.

\section{UCAPAN TERIMA KASIH}

Penulis mengucapkan terima kasih kepada Universitas Padjadjaran sebagai institusi yang menaungi penulis atas Hibah Internal Unpad yang diberikan dengan skema Riset Dosen Pemula Unpad (RDPU), sehingga penelitian ini dapat terlaksana. Ucapan terima kasih juga penulis sampaikan kepada Prof. Edy Sunardi atas bimbingan kepada penulis, Dr. Iyan Haryanto atas bantuan dalam melakukan penelitian lapangan, dan Dr. Billy G. Adhiperdana atas masukan terhadap manuskrip yang dibuat.

\section{DAFTAR PUSTAKA}

Adhiperdana, B. G. (2018). Sedimentological study of a fluvial succesion of the Eocene-Oligocene Bayah Formation, West Java: Reconstruction of paleohidrological features of an ancient fluvial system using empirical equations developed from modern fluvial systems in the Indonesian islands. Chiba University, Japan. (Unpublished Doctoral Dissertation).

Baumann, P., De Genevraye, P., Samuel, L., Mudjito, \& Sajekti, S. (1973). Contribution to The Geological
Knowledge of South West java. In Indonesian Petroleum Association, Second Annual Convention (pp. 105108).

Bouma, A. H., Berryhill, H. L., Khebel, H. J., \& Brenner, R. L. (1982). Continental Shelf. In P. A. Schole \& D. Spearing (Eds.), Sandstone Depositional Environments: AAPG Memoir 31.

Cant, D. J. (1982). Fluvial Facies Models. In P. A. Schole \& D. Spearing (Eds.), Sandstone Depositional Environments, AAPG Memoir 31 ( $\mathrm{p}$. 410).

Clements, B., \& Hall, R. (2007). Cretaceous to Late Miocene stratigraphic and tectonic evolution of West Java. Proceedings of the Indonesian Petroleum Association, (May), 1-18.

Coleman, J. M., \& Prior, D. B. (1982). Deltaic Environments. In P. A. Schole \& D. Spearing (Eds.), Sandstone Depositional Environments: AAPG Memoir 31.

Darman, H., \& Sidi, H. (2000). An Outline of the Geology of Indonesia. $A$ Special Publication of the Indonesian Association of Geologist (IAGI).

Demaison, G., Holck, J. J., Jones, R. W., \& Moore, G. T. (1983). PD 1(2) Predictive Sourcebed Stratighraphy: A Guide to Regional Petroleum Occurence. In 11th World Petroleum Congress. World Petroleum Congress.

Dembicki, H. (2009). Three common source rock evaluation errors made by geologists during prospect or play appraisals. AAPG Bulletin, 93(3), 341-356. https://doi.org/10.1306/10230808076

Effendi, A. C., \& Hermanto, B. (1986). Peta Geologi Lembar Bogor, Jawa Barat, Skala 1: 100.000. Direktorat Geologi, Departemen Pertambangan, Bandung.

Espitalié, J., Madec, M., Tissot, B. P., Mennig, J. J., \& Leplat, P. (1977). Source rock characterization method for petroleum exploration. Offshore Technology Conference, Houston, 439-444. https://doi.org/10.4043/2935-ms 
Hakimi, M. H., \& Abdullah, W. H. (2013). Organic geochemical characteristics and oil generating potential of the Upper Jurassic Safer shale sediments in the Marib-Shabowah Basin, western Yemen. Organic Geochemistry, 54, 115-124. https://doi.org/10.1016/j.orggeochem. 2012.10.003

Langford, F. F., \& Blanc-Valleron, M. M. (1990). Interprting Rock-Eval Pyrolosis Data Using Graphs of Pyrolizable Hydrocarbons vs. Total Organic carbon. The America Association of Petroleum Geologists Bulletin, 74(6), 799-804.

Lüniger, G., \& Schwark, L. (2002). Characterisation of sedimentary organic matter by bulk and molecular geochemical proxies: An example from oligocene maar-type Lake Enspel, Germany. Sedimentary Geology, 148(1-2), 275-288. https://doi.org/10.1016/S00370738(01)00222-6

Martodjojo, S. (2003). Evolusi Cekungan Bogor, Jawa Barat. Bandung: ITB.

Martodjojo, S. (1984). Evolution of Bogor Basin, West Java. Institut Teknologi Bandung.

McCarthy, K., Rojas, K., Niemann, M., Palmowski, D., Peters, K., \& Stankiewicz, A. (2011). Basic Petroleum Geochemistry for Source Rock Evaluation. Oilfield Review, 23(2), $32-43$. https://doi.org/10.1016/j.epsl.2006.01 .027

Peters, K. E. (1986). Guidelines for Evaluating Petroleum Source Rock Using Programmed Pyrolysis. The American Association of Petroleum Geologists Bulletin, 70(3), 318-329.

Peters, K. E., \& Cassa, M. R. (1994). Applied Source Rock Geochemistry. AAPG Memoir 60, (January 1994), 93-120.

Purnomo, E., Ryacudu, R., Sunardi, E., \& Koesoemadinata, R. P. (2006). Paleogene sedimentation of the jatibarang sub-basin and its implication for the deep play petroleum system of the Onshore Northwest Java Basin, Indonesia. In Jakarta International Geosciences Conference and Exhibition Proceedings.

Remington, D. H., \& Pranyoto, U. (1985). A hydrocarbon generation analysis in the N.W. Java basin using Lopatin's method. In Indonesia Petroleum Association, Fourth Annual Convention Proceedings.

Samuel, \& Mujito. (1976). A Geological Guide Along the Road Between Cibadak Pelabuhanratu (Southwest Java).

Song, J., Littke, R., Weniger, P., OstertagHenning, C., \& Nelskamp, S. (2015). Shale oil potential and thermal maturity of the Lower Toarcian Posidonia Shale in NW Europe. International Journal of Coal Geology, 150-151, 127-153. https://doi.org/10.1016/j.coal.2015.08 .011

Sunardi, E., \& Adhiperdana, B. G. (2008). An Account for the Petroleum Prospectivity of the Southern Mountain of West Java: A Geological Frontier in the West? In Indoesia Petroleum Association, 32nd Annual Convention Proceeding.

Sunardi, E., \& Adhiperdana, B. G. (2013). Sedimentologi dan Paleohidrologi Sedimen Fluvial Oligosen Formasi Walat, Sukabumi-Jawa Barat. Bionatura, 15(1), 8-13.

Tissot, B. P., \& Welte, D. H. (1985). Petroleum Formation and Occurrence. Springer-Verlag, Berlin, Germany. https://doi.org/10.1029/EO066i037p0 0643

Waples, D. W. (1985). Geochemistry in petroleum exploration. D. Reidel Publishing Company. https://doi.org/10.1007/978-94-0095436-6

Zielger, V. (1918). The Movements of oil and Gas through Rocks. Economic Geology, 13(5), 335-348.

\begin{tabular}{|ll|}
\hline Diterima & $: 11$ Januari 2018 \\
Direvisi & $: 23$ Januari 2018 \\
Disetujui & $: 28$ Mei 2018 \\
\hline
\end{tabular}

